\title{
An Investigation into the Challenges Preventing Students of Educational Administration and Planning from Using ICT for Learning in Nigeria Higher institutions
}

\author{
Ogunode Niyi Jacob \\ Federal University, Wukari, Taraba State, Nigeria. \\ *Correspondence: Ogunodejacob@gmail.com
}

\begin{abstract}
The main purpose of this research work was to investigate the challenges preventing students of educational administration and planning from using ICT for learning in Nigeria higher institutions: a case study of university of Abuja, Nigeria. The sample for this study was all the students in university of Abuja. 50 students from each level of the department of educational administration and planning totaling 200were randomly selected from the department using simple random sampling technique. One hypothesis and three research questions were postulated as a guide to this study and a seven subitems questionnaire divided into two sections was used to get the required information. A simple percentage and chi-square was used to test the hypotheses at $0.95 \%$ level of significance. It was found out that there are challenges preventing students of educational administration and planning from using ICT for learning. The challenges preventing students of educational administration and planning from using ICT for learning includes; unstable power supply, lack of personal laptop or computer system, unstable ICT Network services, lack of computer literacy by the students, High cost of ICT services, poor infrastructural facilities of ICT in higher institutions and poor computer literacy of the lecturers. Base on the findings, the researchers recommends that the government should increase the funding of education in Nigeria to enable schools administrators provide necessary ICT facilities in their various schools.
\end{abstract}

Keywords: Planning, Administration, Students and challenges.

\section{INTRODUCTION}

Nigeria has a federal system of government with 36 states and the Federal Capital Territory of Abuja. Within the states, there are 744 local governments in total. Education is administered by the federal, state and local governments. The Federal Ministry of Education is responsible for overall policy formation and ensuring quality control, but is primarily involved with tertiary education. School education is largely the responsibility of state (secondary) and local (elementary) governments. The country is multilingual, and home to more than 250 different ethnic groups. The languages of the three largest groups, the Yoruba, the Ibo, and the Hausa, are the language of instruction in the earliest years of basic instruction; they are replaced by English in Grade 4. Nigeria's education system encompasses three different sectors: basic education (nine years), post-basic/senior secondary education (three years), and tertiary education (four to six years, depending on the program of study).

According to Nigeria's latest National Policy on Education (2004), basic education covers nine years of formal (compulsory) schooling consisting of six years of elementary and three years of junior secondary education. Post-basic education includes three years of senior secondary education. At the tertiary level, the system consists of a university sector and a non-university sector. The latter is composed of polytechnics, mono technics, and colleges of education. The tertiary sector as a whole offers opportunities for undergraduate, graduate, and vocational and technical education.

The Nigerian higher education system is comprised of Universities, Polytechnic and Colleges of Education offering programs in areas such as teacher education and agriculture. It is the largest and most complex higher education system on the continent.

The National Universities Commission (NUC) in Nigeria is the only body saddled with the responsibility of managing the Nigerian universities. The commission in different times has come up with policies to integrate ICT into the Nigerian Universities education system for a total development of the country. According to Okhiria (2007) who noted that National Universities Commission (NUC) in Nigeria has prescribed that there should be at least one computer to every four students and one PC to every two lecturers below the grade of lecturer I, one PC per senior lecturer and one notebook per reader/ professor. NUC has gone further to establish e-learning platforms fitted with twenty smart boards in twelve Federal universities for the promotion of the use of ICT in teaching and learning. Majority of the Nigerian universities have not achieved this recommended system ratio for their faculties, though some have made giant or notable strides in campus wide area networking and e-learning course deliveries. 
Institutions like Obafemi Awolowo University (OAU) and University of Nigeria, Nsukka boast of its best-developed ICT system in the country with a personal VSAT access to the internet and a campus wide intranet services. University of Jos which is blazing the trail for content development and elearning in addition to the campus networking, (Liverpool et al, 2009).

The used of ICT in the Nigerian universities both public and private have not been encouraging. According to Adavbiele (2016) very few of Public higher institutions in the country are capable of meeting the ICT needs of their staff and students. The question now is what happens to the rest institutions? Many university lecturers and students have to go to commercial cyber cafés in town before they have access to a computer that is internet connected or at best buy private models with which they are able to connect to the internet.

The private universities seem to be better off since majority of them like Covenant University (CU), Afe Babalola University, American University of Nigeria (AAUN), etc have 24-hour internet connectivity in their campuses but the population of lecturers and students compared to public universities are few. At AAUN for instance, each student is provided a laptop with the cost factored into the fee structure. That of course will not be within the reach of many students (Adavbiele, 2016).

Cheung and Huang (2005) emphasized the use of ICT as an effective teaching tool in university education as many university teachers now publish their course materials via the internet. They suggested that it is insufficient for only university to use ICT for good job combination leaving out the students' ability to do same.Educational technologists have cited may reasons as to why an education system based on ICT can more effectively result in positive pedagogic outcomes than one based only on conventional techniques (Balanskat, Blainire and Kefala, 2006; Means et al, 1993; Roblyer and Edwards, 2000; Than, 2006 and Ting, 2005).

Students formed the largest part of any academic community and their viewpoint has to be respected. Considering the role they play in any activity that takes place in the school settings, psychologist argued that student should be seen as dynamic and integral members of the learning community not just as aloof beneficiaries or even a mere consumers. Amayuayi (2012) is in the feeling that ICT evacuates issues concerning space and time where students can correspond with their teacher and exchange information anywhere, anytime. As a rule the students can bring from a worldwide pool of learning as ICT makes serving and sharing of information simpler. The learners can exclusively and/or together make notes and presentations therefore enlist their advancement and use it for examinations along these lines they are additionally prepared for future support in worldwide exploration and correspondence. Once more, partners in the field of instruction technology agreed that ICT in training will promote students cognitive qualities through higher order thinking, critical reasoning, enhanced relational abilities and profound comprehension of the learning apparatuses and ideas to be taught. Promoting a strong, intuitive educating and learning environment by making more extensive learning correspondence and hence give learning instruments to students particularly those with exceptional needs. Utilizing computer produced design to outline connections of numerous types particularly methods that can't be represented manually by individual (Amajuoyi, 2012)

There are many challenges that prevents students of higher institutions in Nigeria from using ICT for effective learning. This paper is aimed to investigate the challenges preventing students of educational administration and planning from using ICT for learning in Nigeria higher institutions: a case study of university of Abuja, Nigeria.

\section{STATEMENT OF THE PROBLEM}

According to Adavbiele (2016) there are significant bodies of research relating to the obstacles of ICT integration in teaching and learning in the developed countries such as US and UK, but in the developing countries like Nigeria, especially at the university level, such publications are few and scanty in scope, if they exit at all. Whereas such publications are valuable information sources for countries which would like to improve and make a success on ICT tools integration in teaching and learning. Apagu and Wakili (2015), observed that most of the research works on ICT in education focuses on the availability of the ICT facilities and the perceptions of the use of ICT in the nation's institutions. There have been many researchers in ICT uses in primary schools, ICT application in senior secondary schools and challenges confronting ICT uses in higher institutions but none of the researchers have narrow research to the students of educational administration and planning students. It is against this back ground that I decided to research on this study to investigate the challenges preventing students of educational administration and planning from using ICT for learning in Nigeria higher institutions: a case study of university of Abuja, Nigeria and to suggest possible solutions to the challenges identified in the study.

\section{LITERATURE REVIEW}

\subsection{Concept of Educational administration and planning in Nigerian Higher institutions}

Educational administration and planning was introduced into the Nigerian Higher institutions with the aims of producing educational administrators and planners for all phases of the educational sector in Nigeria. Educational administration and planning is offer in most Nigerian universities as a programme or department. Educational administration and planning is also offer as an elective course in 400 levels. The nomenclature of the programme is Bachelor of Arts education i.e B.A [Ed] Educational administration and planning. The duration of the programme is four [4] academic section. The minimum credit unit required for graduation is 148. The admission requirements entry into the programme in universities is five Credits at SSCE, GCE ' $\mathrm{O}$ ' Level, NECO and NABTEB Including English Language, Mathematics and other relevant 
three credit passes and Unified Tertiary Matriculation Examination [UTME], the candidate shall be required to pass the University post UTME Screening test before being admitted for hundred level [100L].

\subsection{Objectives of educational administration and planning in Nigerian Higher institutions}

-To raise an educational administrators and planners who are confidence, independence, efficient, -visionary and innovative and problem solving in the educational sectors;

-To create in students the awareness and enthusiasm for educational administration and planning;

-To generate in students an appreciation of the importance administration and planning in education, economic, technological and social context;

-To provide students with the knowledge and skill-base for further studies in projection, forecasting, statistics, microplanning, data management and demography;

-To provide a broad and balance foundation, knowledge and practical skills in educational administration and planning.

The students offering educational administration and planning in Nigerian higher institutions are many. The knowledge of ICT is very important for them due to their functions and responsibilities as an educational administrators and planners. As leaners in the universities, they need to be computer literate. It is strongly believed that ICT can facilitate the teaching methods and encourage learners' understanding as can be seen in using softwares like CAI, CAL, CBT etc. Numerous studies have discovered constructive outcome connected with innovation supported teaching and learning (Burnett, 1994, and Fitzgerald and Warner, 1996).

Abubakar (2016) Modern instructional techniques required the use of ICT which provide a more simplified and reliable teaching and learning methodologies. From the students viewpoint the integration of ICT education help in both cooperative and self-paced learning. Students can adjust their learning paces with immediate feedback and self-assessment in an institution where the new technologies are being used. Such students extend their learning capabilities beyond classrooms as they can communicate with peers from everywhere around the globe. This novel achievement of the 21 st century is presently not fully employed in the northeastern region of Nigerian public secondary schools. This negative development might not be unconnected with the lack of ICT facilities in our public schools, negligence from the authorities concerned or the misuse of the available ICT equipment on the ground by the teachers. This unfortunate situation is in fact, what motivates the researcher to evaluate the level of ICT usage in our public secondary schools.

According to Sherrelle (2012), a 21st century student is one who learns or works collaboratively with class mates and other peers around the world in a global classroom. Unlike in the past, where students sees as someone who goes to school, spent a specific amount of time take recommended subjects receive a passing grades and finally graduate.
Uses of ICT in Educational institutions in Nigeria

Obunadike (2009) carried out a research to investigate Implementing ICT Techniques in Teaching for effective implementation of the new nine years UBE curriculum is the objective of this research study. The study investigated the effective implementation of ICT in the new nine years UBE curriculum. The survey was based on four research questions. A sample total of 3048 science and non-science teachers consisting of 551 science teachers from private primary and 823 science teachers from public junior secondary schools, and 731 non-science teachers from private primary and 943 non-science teachers from government owned junior secondary school from the six different educational zones in Anambra State. A questionnaire titled "implementing ICT Techniques in Teaching for Effective Implementation of the New UBE Curriculum" (IICTEINUBEC) was used for data collection. Data was analyzed using mean ratings. The Findings include that the schools did not have ICT course outlines specifying the progressive topics to be learnt by primary and Secondary school students, science based subjects which require the use of ICT for its effective teaching / learning are not being used.

Adeyemi, and Olaleye, (2010) did a study to investigate the use of information communication and technology (ICT) for effective management of secondary schools in Ekiti State, Nigeria. The study was a descriptive survey. The study population comprised all the 182 secondary schools in the State. Out of this population, a sample of 160 secondary schools was taken and selected through the stratified random sampling technique. Out of the 6,278 teachers in the schools, 812 teachers made up of 160 principals and 652 teachers were selected for the study. The method of selection was also through the stratified random sampling technique. The instrument used to collect data for the study was a questionnaire while the data collected were analyzed using frequency counts, percentages and Pearson Product Moment Correlation analysis. It was found that the level of provision of ICT equipment to secondary schools in the State was low. The level of principals' management of schools was also low. The intermittent disruption of electricity and inadequate funding were found as major problem inhibiting the usage of ICT equipment for the management of schools in the State. It was concluded that the State government was not fully ready to imbibe (ICT) for the effective management of secondary schools in the State. It was recommended that the State government should supply the necessary ICT equipment to all secondary schools in the State. Government should also improve the training of principals, teachers and computer personnel in the use of computers and other ICT equipment through seminar, workshop and in-service training.

Abubakar (2016) the application of information and communications technology in Nigeria and in African countries generally is increasing and dramatically growing. Over the past few years, ICT has turned out to be a step by step more imperative to schools at all levels and to the entire education system at large. There exist an extensive variety of researches focused on the investigation of the utilization of 
ICT in the process of teaching and learning in Nigerian secondary schools. This study aimed to assess how ICT is used in teaching and learning in Nigerian public secondary schools particularly those from the Northeastern States from the viewpoint of students, instructors and administrators. Built on the three central research questions, the objective of this study is to assess the degree of usage of the ICT facilities in teaching and learning practices. In this study, a mixed-methods approach for data gathering was applied by using questionnaires and interviews to collect data from students, instructors and administrators in the studied states. The responses were then analyzed based on the research questions outlined in chapter one. The result shows that the use of ICT facilities are very low and this is attributed to the poor policy implementation, lack of basic social amenities and insecurity.

Adavbiele, (2016) observed that today, information and communication technology (ICT) is very important in the learning and teaching process at all levels of education. However, in Nigeria the use of ICT is still at its infancy. If the educational system in Nigeria is to match with global requirements, there is need to incorporate the use of ICT that facilitates knowledge acquisition within and beyond the classroom. This paper examines the gap and challenges facing the use of ICT in university education in Nigeria. The study is a descriptive survey that assessed five universities for the most urgent solution. The population of the study was 120 respondents and this is made up of university lecturers and the students. Findings revealed that there is a gap between the university teachers and students and ICT usage in classroom sand many university lecturers and students have to go to commercial cyber cafés in town before they have access to a computer that is internet connected, teachers are faced with some challenges and barriers of availability of facilities which prevent them to employ ICT in the classroom, the solutions proffered include funding, provision of facilities and technical expertise in Nigeria universities.

\section{PURPOSE OF THE STUDY}

The aim of this study is to investigate the challenges preventing students of educational administration and planning from using ICT for learning in Nigeria higher institutions: a case study of university of Abuja, Nigeria. Specifically the study intend to:

1) Find out the challenges preventing students of educational administration and planning from using ICT for learning in Nigeria higher institutions;

2) Investigate how educational administration has personal laptop system or computer system;

Number of Respondents (Students) in Schools The population and distribution of the respondents across all the department of educational administration and planning is presented in Table 1.
3) Investigate the extent of usage of ICT in learning educational administration and planning.

\subsection{Research questions}

The following research questions were raised to guide the study.

1) What are the challenges preventing students of educational administration and planning from using ICT for learning in Nigeria higher institutions?

2) Do all the students of educational administration and planning have personal laptop system or computer system?

3) To what extent do the students of educational administration and planning used ICT for learning?

\subsection{Research Hypothesis}

One research hypothesis was developed for this study;

1) There are no challenges preventing students of educational administration and planning from using ICT for learning.

\section{RESEARCH METHODOLOGY}

The research design adopted for this study was survey design. This design is used in this study in view of the fact that the research is undertaken when there are qualitative and quantitative analysis of the research. This research was carried out in the Federal Capital Territory, Abuja, Nigeria using university as a case study. The population of the study consisted of 12,000 students in all.

Stratified random sampling was employed as sampling technique to select two hundred students of educational administration and planning students of the university in the faculty of education. After stratification, a simple random sampling technique was adopted to select the respondents in the department of educational administration and planning, faculty of education. Two hundred students fifty from each level making it a total of two hundred respondents. The instrument used for data collection was a Questionnaire titled: An investigation into challenges preventing students of educational administration and planning from using ICT for learning questionnaire (AICPSEA). The research instrument was constructed and developed by the researcher and given to experts in educational administration and planning to face validate and ascertain the degree of accuracy with which the instrument measures what it was designed to measure. The reliability of the instruments was established through a trial test. The measures of the instruments used in this study were scored on a four point Likert scale format. The data was analyzed using simply percentage and Chi-square test statistical tool.

\section{Results Analysis and Discussion Section A}

The bio-data analysis of the respondents is analyzed below; 
Table 1: Number of Respondents (Students) in selected in the department

$\begin{array}{ll}\text { Levels } & \text { No Of Students } \\ 100 & 50 \\ 200 & 50 \\ 300 & 50 \\ 400 & 50 \\ \text { Total } & 200\end{array}$

The information on Table 1 indicates that 50 students sampled are evenly selected in the department of educational administration and planning university of Abuja to make up a total of 200 respondents used in the study. Gender Distribution

\begin{tabular}{llc} 
Gender & Frequency & Percentage \\
\hline Female & 120 & 60 \\
Male & 80 & 40 \\
Total & 200 & 100
\end{tabular}

Table 2 indicates that $40 \%$ of the respondents were male and $60 \%$ were female. It confirms that there were more female (216) respondents than male (144).

\section{Section B}

Research Question One

Table One: Responses on: If there are challenges preventing students of educational administration and planning from using ICT for learning in Nigeria higher institutions

\begin{tabular}{|c|c|c|c|c|c|c|c|c|}
\hline $\mathrm{S} / \mathrm{N}$ & $\begin{array}{l}\text { All the following are challenges preventing } \\
\text { students of educational administration and } \\
\text { planning from using ICT for learning in } \\
\text { Nigeria higher institutions } 200\end{array}$ & $\begin{array}{l}\text { Strongly } \\
\text { Agree }\end{array}$ & Agree & $\%$ & Disagree & $\begin{array}{l}\text { Strongly } \\
\text { Disagree }\end{array}$ & $\%$ & Total \\
\hline 1 & Unstable power supply & 82 & 58 & $140(70)$ & 31 & 29 & $60(30)$ & 200 \\
\hline 2 & Lack of personal laptop & 109 & 71 & $180(90)$ & & 20 & $20(10)$ & 200 \\
\hline 3 & Unstable ICT Network services & 78 & 52 & $130(65)$ & 55 & 15 & $70(35)$ & 200 \\
\hline 4 & Lack of computer literacy by the students & 71 & 56 & $127(63.5)$ & 60 & 13 & $73(36.5)$ & 200 \\
\hline 5 & High cost of ICT services & 91 & 72 & $163(81.5)$ & 20 & 17 & $37(18.5)$ & 200 \\
\hline 6 & $\begin{array}{l}\text { Poor ICT infrastructural facilities in higher } \\
\text { institutions }\end{array}$ & 79 & 58 & $137(68.5)$ & 43 & 20 & $63(31.5)$ & 200 \\
\hline 7 & Poor computer literacy of the lecturers & 67 & 56 & $123(61.5)$ & 57 & 20 & $77(38.5)$ & 200 \\
\hline
\end{tabular}

Result from research question one and table one for item one showed that $140(70 \%)$ of the sampled respondents agreed that unstable power supply is one of the challenges preventing students of educational administration and planning from using ICT for learning in Nigeria higher institutions while $60(30 \%)$ disagreed. This result affirms the submission of Item two on table one showed that $180(90 \%)$ of the sampled respondents agreed that lack of personal laptop is another challenges preventing students of educational administration and planning from using ICT for learning in Nigeria higher institutions while $20(10 \%)$ disagreed. This result is in line with Abubakar (2016) who observed that teachers and school administrators are skeptical about the challenges facing the integration of ICTs in teaching-learning process. These include; poor electric power supply, lack of knowledgeable ICT support personnel, inadequacy of trained teachers in the field of ICT, lack of funds and high cost of ICT equipment. 
Result of item three on table one also revealed that that $130(65 \%)$ of the sampled respondents agreed that unstable services is one of the major challenges preventing students of educational administration and planning from using ICT for learning in Nigeria higher institutions while $70(35 \%)$ disagreed. This result agreed with the discovered of Fakeye (2010) who reported that in Ibadan that in a large portion of schools studied don't have PCs, henceforth are not associated with the web (internet).

Item four result on table one showed that that $127(63.5 \%)$ of the sampled respondents agreed that lack of computer literacy by students of educational administration and planning is one of the major challenges preventing students of educational administration and planning from using ICT for learning in Nigeria higher institutions while 73(36.5\%) disagreed.

Result of item five on table one also revealed that that $163(81.5 \%)$ of the sampled respondents agreed that high cost of services of ICT network is among the challenges preventing students of educational administration and planning from using ICT for learning in Nigeria higher institutions while $37(18.5 \%)$ disagreed. This result of item four and five is in agreement with the opinion of Abubakar(2016) who observed that teachers and school administrators are skeptical about the challenges facing the integration of ICTs in teaching-learning process. These include; poor electric power supply, lack of knowledgeable ICT support personnel, inadequacy of trained teachers in the field of ICT, lack of funds, high cost of ICT equipment, materials and accessories, government's payment to support the implementation of ICT policies, inadequate telephone services, lack of proper maintenance of the broken down equipment and facilities and shortage of ICT facilities.

Result of item six on table one showed that that $137(68.5 \%)$ of the sampled respondents agreed that poor ICT infrastructural facilities in higher institutions is another major challenges preventing students of educational administration and planning from using ICT for learning in Nigeria higher institutions while $63(31.5 \%)$ disagreed. This result supported the findings of

Item seven result of table one revealed that that $123(61.5 \%)$ of the sampled respondents agreed that poor computer literacy of the lecturers is one of the major challenges preventing students of educational administration and planning from using ICT for learning in Nigeria higher institutions while 77(38.5\%) disagreed. This result According to Osakwe (2012), acquisition, deployment and management of information technology resources and services for teaching depend on electricity. Studies have shown that poorly maintained equipment and poor network infrastructure are prominent obstacles to the integration of ICT tools in teaching.

\section{Research Question Two}

Table Two: Responses on: If all the students of educational administration and planning have personal laptop system or computer system.

\begin{tabular}{|c|c|c|c|c|c|c|c|c|}
\hline $\mathrm{S} / \mathrm{N}$ & Items & $\begin{array}{l}\text { Strongly } \\
\text { Agree }\end{array}$ & Agree & $\%$ & Disagree & $\begin{array}{l}\text { Strongly } \\
\text { Disagree }\end{array}$ & $\%$ & Total \\
\hline 1 & $\begin{array}{l}\text { All the students of educational administration } \\
\text { and planning have personal laptop system or } \\
\text { computer system }\end{array}$ & 21 & 7 & $28(14)$ & 60 & 112 & $172(86)$ & 200 \\
\hline
\end{tabular}

Responses on if all the students of educational administration and planning have personal laptop system or computer system on table two showed that $28(14 \%)$ of the sampled respondents agreed that all the students of educational administration and planning have personal laptop system or computer system while $172(86 \%)$ disagreed. This result implies that majorities of the students of educational administration and planning in Nigeria higher institutions do not have personal laptop system or computer system.

\section{Research Question Three}

Table three: Responses on: If Students of educational administration and planning do used ICT for learning of educational administration and planning regularly

\begin{tabular}{|l|l|l|l|l|l|l|l|l|}
\hline S/N & Items & $\begin{array}{l}\text { Strongly } \\
\text { Agree }\end{array}$ & Agree & $\%$ & Disagree & $\begin{array}{l}\text { Strongly } \\
\text { Disagree }\end{array}$ & $\%$ & Total \\
\hline 1 & $\begin{array}{l}\text { Students of educational administration } \\
\text { and planning use ICT for learning of } \\
\text { educational administration and planning } \\
\text { regularly }\end{array}$ & 4 & 19 & $23(11.5)$ & 67 & 110 & $177(88.5)$ & 200 \\
\hline
\end{tabular}


Responses on if Students of educational administration and planning do used ICT for learning of educational administration and planning regularly in the school on table

three revealed that $23(11.5 \%)$ of the sampled respondents agreed that students of educational administration and planning used ICT for learning of educational administration and planning regularly while $177(88.5 \%)$ disagreed. This result means that higher institutions in Nigeria do not regularly used ICT for teaching and learning.

\section{Test of Hypothesis}

The chi-square test was adopted to test the hypothesis. The level of confidence chosen is $95 \%$ using the Murray's formula: The formula is stated as follows:

$\mathrm{X}^{2}=\Sigma(\mathrm{Oi}-\mathrm{Ei})^{2}$

ei

Where:

$\mathrm{X} 2=$ Measurement of discrepancy existing between the observed and expected frequencies
$\mathrm{O} i=$ observed frequencies

$\mathrm{Oe}=$ expected frequencies

$\Sigma=$ summation

The decision rule with regards to the above statistical formula is that where the computed value of X2 exceeds its critical or table value, the 'null hypothesis' (Ho) is rejected and the 'alternative hypothesis (Hi) is accepted. But where the computed value of $\mathrm{X} 2$ equals or is less than that of the critical or table value, the null hypothesis (Ho) is accepted.

\section{Hypothesis one}

Ho: There are no challenges preventing students of educational administration and planning from using ICT for learning.

Hi: There are challenges preventing students of educational administration and planning from using ICT for learning.

Table one: Responses on: If are challenges preventing students of educational administration and planning from using ICT for learning.

\begin{tabular}{|l|l|l|l|l|l|l|l|}
\hline S/N & Items & $\begin{array}{l}\text { Strongly } \\
\text { Agree }\end{array}$ & Agree & $\%$ & Disagree & $\begin{array}{l}\text { Strongly } \\
\text { Disagree }\end{array}$ & $\begin{array}{l}\% \\
\text { Total }\end{array}$ \\
\hline 1 & $\begin{array}{l}\text { There challenges preventing students of } \\
\text { educational administration and planning from } \\
\text { using ICT for learning? }\end{array}$ & 111 & 29 & $140(70)$ & 43 & 17 & $60(30)$ \\
\hline
\end{tabular}

\begin{tabular}{|l|l|l|l|}
\hline S/N & Responses & No of Respondents & Percentage \\
\hline Yes[ Agreed] & 140 & - & 70 \\
\hline No [Disagreed] & 60 & - & 30 \\
\hline Total & 200 & - & 100 \\
\hline
\end{tabular}

\section{TEST OF HYPOTHESES}

Calculated of Expected Frequency

$\mathrm{Ei}=$ Total Observed Frequency

Number of response

$\mathrm{Ei}=200 / 4$

$\mathrm{Ei}=50$

The degree of freedom (df) is found by the formula $(n-I)$

TABLE four: TEST OF HYPOTHESES

Contingency table

\begin{tabular}{|c|c|c|c|c|c|}
\hline Responses & Oi & $\mathrm{Ei}$ & $\mathrm{Oi}-\mathrm{Ei}$ & $(\mathrm{Oi}-\mathrm{Ei})^{2}$ & $\frac{(\mathrm{Oi}-\mathrm{Ei})^{2}}{\mathrm{Ei}}$ \\
\hline Yes & 140 & 50 & -90 & 8100 & 165 \\
\hline No & 60 & 50 & -10 & 100 & 10 \\
\hline Total & 200 & & & & 175 \\
\hline
\end{tabular}


Decision Rule: As the table 1 shows the table value shows the table value 150 is greater than the critical value. Using the decision rule, the null hypothesis (H0) is rejected while the

alternative hypothesis (H1) which states that there are challenges preventing students of educational administration and planning from using ICT for learning is accepted.

\section{Interpretation}

Since the calculated value $X^{2}=150$ is greater than the computed value. We rejected the hull hypothesis (Ho) and accept the alternative hypothesis (Hi).There are challenges preventing students of educational administration and planning from using ICT for learning.is accepted.

Hypothesis I

\section{Decision Rule}

Reject Ho, if $\mathrm{X}^{2}>\mathrm{X}^{20}$

Accept Ho, if $X^{2} \leq X^{20}$

There are challenges preventing students of educational administration and planning from using ICT for learning.

\section{CONCLUSION}

This result collected established the fact that there are challenges preventing students of educational administration and planning from using ICT for learning.

The paper established the following challenges preventing students of educational administration and planning from using ICT for learning to includes; unstable power supply, lack of personal laptop or computer system, unstable ICT Network services, lack of computer literacy by the students, High cost of ICT services, poor infrastructural facilities of ICT in higher institutions and poor computer literacy of the lecturers.

It was also discovered that $86 \%$ of the respondents disagreed agreed that majorities of the students of educational administration and planning in Nigeria higher institutions do not have personal laptop system or computer system and that higher institutions in Nigeria do not regularly used ICT for teaching and learning.

Base on the findings, the researchers recommends the following;

$=$ The government should increase the funding of education in Nigeria to enable schools administrators provide necessary ICT facilities in their various schools;

= A policy should be designed to allow students and lecturers own a laptop or computer and pay install mentally.

$=$ The higher institutions authorities should make teaching and learning $70 \% \mathrm{ICT}$;
$=$ The students and lecturers should be trained on computer literacy;

$=$ The government should provide modern computers with soft-ware in all higher institutions in the country;

$=$ The ICT services providers should improve on the quality of services supplying to the higher institutions in Nigeria to ensure stable services always;

$=$ The government should reduce the prices of ICT facilities for higher institutions in the country.

\section{REFERENCES}

Ämajuoyi, J. J. (2012). Towards effective integration of information and communication technology in universal basic education: issues and challenges to ST in education. Journal of 52 annual conference of science teachers association of Nigeria 2012. HEBN publishers' plc.

Adeyemi, T.O and Olaleye, F.O (2010) Information Communication and Technology (ICT) for the Effective Management of Secondary Schools for Sustainable Development in Ekiti State, Nigeria. American-Eurasian Journal of Scientific Research 5 (2): 106-113, 2010 ISSN 1818-6785

Abubakar M, A. (2016). An Assessment of the Use of ICT in Teaching and Learning in Public Secondary Schools in Northeastern Nigeria. Master Thesis

Adavbiele, J, A. (2016). The use of ICT to enhance University education. International Journal of Education, Learning and Development Vol.4, No.5, pp.1-11.

Abdul-Salaam, A. O. (2012). Assessment of secondary school teachers' use of information and communication technology (ict) in oyo metropolis of oyo State. Proceedings of the 1st International Technology, Education and Environment Conference (c) African Society for Scientific Research (ASSR). Balanskat, A; Blainire, R and Kefala, K. (2006).A review of studies of ICT input on schools in Europe. European School.net.

Evoh, C. J. (2007). Policy networks and the transformation of secondary education through ICTs in Africa: the prospects and challenges of the NEPAD e-Schools initiative. International journal of Education and Development using information and communication technology (IJEDICT) 3 (1), 64-

84.Retrieved from http://www.ijedct.dec.uwi.edu/include/gedoc.php.

Fakeye, D. O. (2010).Assessment of English Language Teachers' Knowledge and Use of Information and Communication Technology (ICT) in Ibadan Southwest Local Government of Oyo State. American-Eurasian Journal of Scientific Research.5 (4).56-59.

Fedeal Republic of Nigeria, (2004). National policy on education 4th edition. Lagos, Nigeria Educational Research and Development Council.

Osakwe, R, N. (2012). Challenges of information and communication technology (ICT) education in Nigerian public secondary schools. Education Research Journal 2(12); 388- 391. Retrieved on the 15thFebruary, 2015 from http://www.resjournals.com/ERJ

Obunadike J, C. (2009)Implementing ICT Techniques in Teaching for the Effective Implementation of the New Nine Years UBE Curriculum in Anambra State (Pp. 367-376).An International Multi-Disciplinary Journal, Ethiopia Vol. 3 (3). 